Indexed by

\title{
THE EFFECTS OF EARTHQUAKE AND TSUNAMI LOADINGS ON STRUCTURAL BEHAVIOR OF REINFORCED CONCRETE BUILDING
}

Nyoman Sutarja

Udayana University,

Faculty of Engineering,

Department of Civil

Engineering,

Denpasar, Indonesia

\author{
Gede Pringgana \\ Udayana University, \\ Faculty of Engineering, \\ Department of Civil \\ Engineering, \\ Denpasar, Indonesia
}

\author{
Made Ari Santi Wikrama \\ Udayana University, \\ Faculty of Engineering, \\ Department of Civil \\ Engineering, \\ Denpasar, Indonesia
}

Crossref

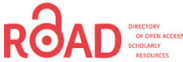

Key words: earthquake loads, tsunami loads, internal forces, drift, drift ratio

KOBSON

Cite article:

Nyoman, S., Gede, P., \& Made, A. S. W. [2021]. The effects of earthquake and tsunami loadings on structural behavior of reinforced concrete building. Journal of Applied Engineering Science, 19(2) 282 - 291. DOI:10.5937/jaes0-25655

Online aceess of full paper is available at: www.engineeringscience.rs/browse-issues 


\title{
THE EFFECTS OF EARTHQUAKE AND TSUNAMI LOADINGS ON STRUCTURAL BEHAVIOR OF REINFORCED CONCRETE BUILDING
}

\author{
Nyoman Sutarja*, Gede Pringgana, Made Ari Santi Wikrama \\ Udayana University, Faculty of Engineering, Department of Civil Engineering, Denpasar, Indonesia
}

This study aimed to evaluate the performance of structures such as drift ratios and internal forces arising on structural components due to earthquake and tsunami loads. The structures were modeled in three dimensions with varying heights of 3, 5, and 7-story according to the allowable building height in Bali, Indonesia. The earthquake load was designed in accordance with Indonesian standard SNI-1726-2012 and Tsunami loading refers to FEMA P646-2012. Three different loads were applied namely earthquake load, combined tsunami load 1 (T1), and combined tsunami load 2 (T2). The results showed that the drift ratios of the 3-story building structure subjected to all loads meets the criteria for a building with risk category IV, should less than 1\%. However, for the 5 and 7 -story building structures, the drift ratio on the first floor was only due to the earthquake load fulfilled (<1\%). The drift ratio of $1.44 \%$ and $2.13 \%$ respectively were due to the loads T1 and T2 for 5-story and $2.88 \%$ and $4.67 \%$ for the 7-story building. These results indicated that the 5-story and 7-story building structure is unable to withstand the lateral forces due to the tsunami load neither load T1 nor T2.

Key words: earthquake loads, tsunami loads, internal forces, drift, drift ratio

\section{INTRODUCTION}

Most of the development and settlement patterns in Indonesia are in coastal areas [1, 2] thus the buildings in these areas are not only prone to earthquake disasters but also disasters that are likely to occur immediately after a large magnitude earthquake namely the tsunami disaster. The southern coastline of Indonesia is an area that has a high level of tsunami hazard [3-6]. During the Indian Ocean tsunami struck Aceh area on December $26^{\text {th }}, 2004$, a large number of reinforced concrete structures both designed and not following the building code suffered partial or total collapse $[7,8]$.

Low-rise wooden frame buildings and unreinforced brick buildings suffer heavy damage due to hydrodynamic pressures generated by the tsunami and collision forces by debris carried by the tsunami waves [9].

To minimize casualties during a tsunami, a strategy for disaster mitigation is needed $[10,11]$. According to FEMA P646 in 2012, most of the tsunami mitigation efforts carried out were vertical evacuations to higher levels of specially designed building structures with construction that could withstand earthquake and tsunami loads [3].

Therefore, this study was conducted to be able to evaluate the effect of earthquake and tsunami loads on the behavior of reinforced concrete structures. The aim is to evaluate the level of resilience of a structure designed to withstand earthquake and tsunami loads [7].

\section{EARTHQUAKE LOAD ANALYSIS}

The earthquake load calculation in this study uses an equivalent static lateral force analysis according to Indonesian Earthquake Code (SNI 1726:2012) and [12]. This is because the hotel building planning is a building with a structure that tends to be square, regular and symmetrical.

The steps undertaken to determine the earthquake loads based on an analysis of equivalent lateral static force are as follows:

\section{Building risk analysis}

In this stage, the steps that must be taken are determining the type and function of the structure to be built and determining the risk categories based on Table 1 of the Indonesian National Standard on Earthquakes, and determining the importance seismic factors $\left(I_{e}\right)$ based on risk category obtained previously.

\section{Regional response spectra}

The followings steps are taken to form the regional response spectra:

1. Determination of the spectral response acceleration at short periods (Ss) and the spectral response acceleration at 1 -second period (S1).

2. The site classifications listed in Table 3 of SNI-17262012 are determined based on the type of soil at the building site [6].

3. Determination of site coefficients ( $F a$ and $F v$ ) in Table 4 and Table 5 of SNI-1726-2012 [3].

4. Determination of maximum spectral response parameters (SMS and SM1) [6].

$S_{M S}=F_{a} S_{s}$

$S_{M 1}=F_{v} S_{1}$ 
5. Determination of earthquake spectrum response plan.

\section{Equivalent static analysis}

The stages of equivalent static analysis are as follows [6].

1. Fundamental period of structure (Ta) obtained by Equation 3.

$T_{a}=C_{t} h_{n}{ }^{x}$

2. Determination of the response modification coefficient $(R)$

3. The seismic response coefficient (Cs) is determined based on Equation 4.

$C_{s}=\frac{S_{D S}}{\left(R / I_{e}\right)}$

4. The seismic base shear force $(V)$ in the specified direction must be determined in accordance with Equation 5.

$V=C_{s} W_{t}$

5. Determination of lateral force between levels. In the equivalent static analysis, earthquake forces that hit the base of the building will be distributed at each floor / building level according to Equation 6.

$F_{i}=\frac{W_{i} \cdot h_{i}^{K}}{\sum_{i=1}^{n}\left(W_{i} \cdot h_{i}^{k}\right)} \cdot V$

\section{TSUNAMI LOAD ANALYSIS}

The tsunami load to be planned on a building structure must take into account the following loads: hydrostatic force, buoyant force, hydrodynamic force, impulsive force, impact force, the force due to water containment from water-borne debris, uplift force on the floor $[13,14]$.

\section{Hydrodynamic force $(F d)$}

Hydrodynamic loads on building structures are applied when there is water flow around the structure or components of the building structure. Hydrodynamic load is a function of flowing fluid density, flow velocity, and structural geometry. Based on FEMA P646 [3], the hydrodynamic force can be calculated using Equation 7 .

$F_{d}=\frac{1}{2} \times p_{s} \times C_{d} \times B \times\left(h u^{2}\right)_{\max }$

\section{Impulsive force (Fs)}

Impulsive force is the force caused by the foremost wave of water that hits a structure so that it puts a heavy impact on the structure. Based on FEMA P646 [3], to get a conservative value, it is recommended that the value of the impulsive force be 1.5 times the hydrodynamic force as written in Equation 8.

$F_{s}=1.5 F_{d}$

\section{Impact force (Fi)}

The impact force from debris carried by water (such as tree trunks, pieces of wood, ships, containers, vehicles, buildings) can be a major cause of building damage. The impact force of debris can be estimated using Equation 9 [3].

$F_{t}=1.3 u_{\text {maks }} \sqrt{k m_{d}(1+c)}$

\section{Debris damming loads (Fdm)}

Damage caused by the accumulation of debris carried by water can produce a force that comes from the water that carries it. The value of this force is determined by the extent of the debris that damages the surface of the structure. The magnitude of this containment effect is calculated by referring to the equation used when calculating the magnitude of the hydrodynamic force, can be seen in equation 10 [3].

$F_{d m}=\frac{1}{2} \times p_{s} \times C_{d} \times B_{d} \times\left(h u^{2}\right)_{\max }$

\section{Lifting force on the floor (Uplift)}

Lift force will work on the floor of a building submerged by a tsunami inundation. The hydrodynamic force can also work vertically on the floor plate. As long as the water flows quickly, rising water can lift the bottom (soffit) of the horizontal component of the structure, adding to the buoyancy upward estimated by Equation 11 [3].

$F_{u}=\frac{1}{2} C_{u} p_{s} A_{f} U_{v}^{2}$

\section{COMBINATION OF TSUNAMI FORCES}

From the combination of tsunami forces on the overall structure, the combination of tsunami loads for building structures is as follows [3].

\section{Tsunami combination 1 (T1)}

Hydrodynamic Drag Force $(F d)+$ Impulsive force $(F s)$.

\section{Tsunami combination 2 (T2)}

Hydrodynamic Drag Force $(F d)+$ Debris damming loads $(F d m)+$ Gaya Impact Force $(F i)$.

\section{RESEARCH METHODS}

This research uses numerical modeling methods with SAP2000 software. The steps taken in this study are as follows.

1. The initial stage of this research is to make a structure model of buildings 3,5 , and 7 floors in accordance with the planned floor plan itself according to the estimation of the researcher.

2. Evaluation for earthquake loads as seen from the comparison between static earthquake loads and 
dynamic earthquake loads and the results of drift between building floors that have met the requirements before the structure is loaded with tsunami loads at a later stage.

3. Analysis of tsunami loads with the calculation of tsunami forces and combination of loading refers to FEMA P646 of 2012 which is then evaluated on the results of structural analysis with tsunami loads. Then compare how the effect of earthquake and tsunami loads on the behavior of building structures as seen from the internal forces, drift, and drift ratios that occur. The results of the comparison will be presented in data tables and graphs [3, 15].

4. From the results of the analysis, conclusions and suggestions are made.

\section{Data collection}

In this planning the data is collected using primary data. Primary data obtained are assumptions and estimates from researchers, such as; structure plans, structural geometry data and loads that will work on buildings.

\section{Data of structures}

The planned structure is the structure of a reinforced concrete moment frame building that is designed with a special moment resisting frame system with the function of a hotel which is also a monumental building located in the Banda Aceh City Center area with class E site on a soft ground location. Building structures with varying heights are buildings 3, 5 and 7 floors with typical floor plans. Typical structure plans for variations in floor height can be seen in Figure 1.

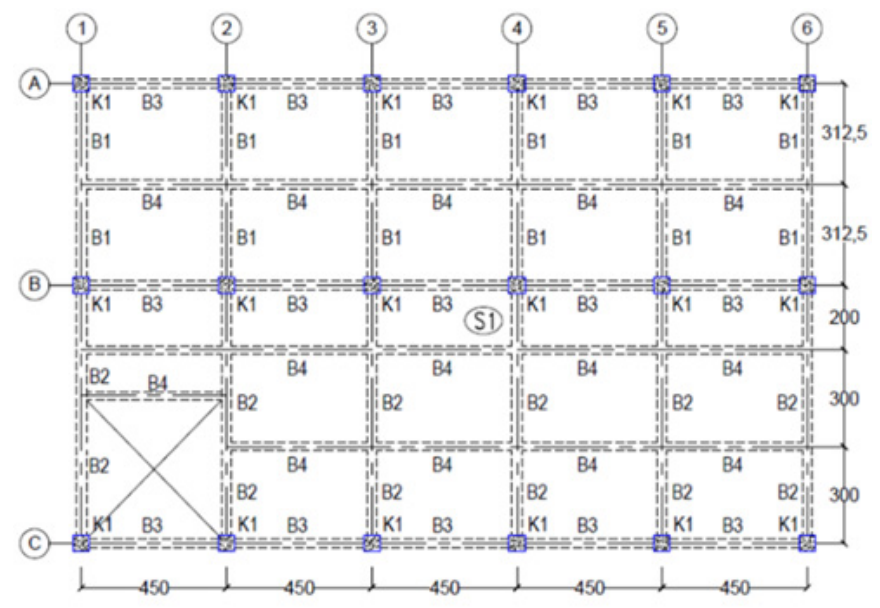

Figure 1: Drawing of a typical floor plan for each floor

\section{Data of material}

The type of material that will be used in building structure planning is reinforced concrete material, with the following data:

1. Concrete Structure Material

Concrete compressive strength $\left(f^{\prime} c\right)=20 \mathrm{MPa}$
Weight of concrete volume $(w c)=2400 \mathrm{~kg} / \mathrm{m}^{3}$

Modulus of elasticity $(E C)=21019 \mathrm{MPa}$

2. Reinforcing Materials

Fy longitudinal reinforcement $(f y)=400 \mathrm{MPa}$

Fy transverse reinforcement $(f y)=240 \mathrm{MPa}$

Column longitudinal reinforcement=D19

Longitudinal Beam Reinforcement=D16, D19

Transverse reinforcement=D10, D12

\section{Structural geometry data}

The building structure made is a frame system of reinforced concrete moment frames, with initial geometry data for structural modeling for each type of building structure as follows:

1. Column $1=500 / 500 \mathrm{~mm}$

2. Column $2=450 / 450 \mathrm{~mm}$

3. Beam $1=300 / 600 \mathrm{~mm}$

4. Beam $2=350 / 700 \mathrm{~mm}$

5. Beam $3=300 / 450 \mathrm{~mm}$

6. B1 roof $=300 / 500 \mathrm{~mm}$

7. B2 roof $=300 / 600 \mathrm{~mm}$

8. B4/ joist $=250 / 400 \mathrm{~mm}$

9. Roof beam $=200 / 400 \mathrm{~mm}$

10. Slab thickness $=120 \mathrm{~mm}$

\section{Data of loadings}

The loadings on the building structure model are as follows:

1. Dead loads and additional dead loads.

Live loads for buildings that function as hotel areas in accordance with SNI-1727-2013, live loads for room floors is $1.92 \mathrm{kN} / \mathrm{m}^{2}$, for corridor floors and evacuation areas on the top floor of buildings is $4.79 \mathrm{kN} / \mathrm{m} 2[16]$.

2. Earthquake load refers to SNI-1726-2012 with the parameters used for analysis as follows:

- risk category=IV

- importance factor of the earthquake le $=1.50$

- coefficient value $\mathrm{Ss}=1.8$ and $\mathrm{S} 1=0.6$

- $\quad$ site class $=\mathrm{SE}$

- response modification factors $(R)=8$

3. Tsunami Loads

Assumptions used to calculate the tsunami load on a building structure:

Building elevation from sea level $(z)=5 \mathrm{~m}$

- Maximum run-up elevation by tsunami inundation $(\mathrm{R})$, and inundation height in building structures are shown in Table 1 to simulate the different type construction in site. 
Table 1: Variation of inundation height

\begin{tabular}{|c|c|c|}
\hline Building Type & $\mathrm{R}(\mathrm{m})$ & $\begin{array}{c}\text { Inundation of } \\
\text { structure }(\mathrm{m})\end{array}$ \\
\hline 3 floors & 9 & 4 \\
\hline 5 floors & 12.5 & 7.5 \\
\hline 7 floors & 16 & 11 \\
\hline
\end{tabular}

\section{Combination of loadings}

1. Earthquake Load Combination

The combination of earthquake loads referring to SNI$1726-2012$ is as follows.

1.2D+1.0L+1.0E

$0.9 \mathrm{D}+1.0 \mathrm{E}$

The combination of earthquake loads used in structural modeling is as follows.

1.2D+1.0L+1.0Ex+0.3Ey

1.2D+1.0L+0.3Ex+1.0Ey

$0.9 \mathrm{D}+1.0 \mathrm{Ex}$

0.9D+1.0Ey

2. Combination of Tsunami Loads

In zones prone to tsunami disasters, building structures must have good durability and serviceability against a combination of tsunami loads and gravity loads. The combination of tsunami loads and the effects of tsunami loads refer to FEMA P646 of 2012, as follows [2][3].

1.2D+1.0Ts+1.0LREF+0.25L

$0.9 \mathrm{D}+1.0 \mathrm{Ts}$

\section{RESULTS AND DISCUSSION}

\section{Earthquake load calculation}

Based on calculations that have been carried out on building risk analysis, formation of regional spectral responses and equivalent static analysis, the calculation of lateral force between floors using Equation 6, the magnitude of lateral forces at each floor is presented in the following Table 2.

Table 2: Lateral forces at each level of a 3-story building

\begin{tabular}{|c|c|c|c|c|c|}
\hline Floor & $w_{i}(\mathrm{kN})$ & $h_{i}$ & $k$ & $w_{i} h_{i}^{k}$ & $F_{i}(\mathrm{kN})$ \\
\hline I & $3,855.97$ & 4 & 1.032 & 21,064 & 415.156 \\
\hline II & $3,689.55$ & 7.5 & 1.032 & 38,511 & 759.023 \\
\hline III & $3,456.93$ & 11 & 1.032 & 53,468 & $1,053.817$ \\
\hline \multicolumn{5}{|c|}{ Total } & $2.227,996$ \\
\hline
\end{tabular}

\section{Evaluation of dynamic earthquake load analysis}

To meet all the performance criteria of building structures against earthquake loads it is necessary to compare the
Table 3: Lateral forces at each level of a 5-story building

\begin{tabular}{|c|c|c|c|c|c|}
\hline Floor & $w_{i}(\mathrm{kN})$ & $h_{i}$ & $k$ & $w_{i} h_{i}^{k}$ & $F_{i}(\mathrm{kN})$ \\
\hline I & $3,855.97$ & 4 & 1.190 & 96,162 & 236.617 \\
\hline II & $3,816.91$ & 7.5 & 1.190 & 200,702 & 493.849 \\
\hline III & $3,700.14$ & 11 & 1.190 & 305,066 & 750.649 \\
\hline IV & $3,583.37$ & 14.5 & 1.190 & 407,914 & $1,003.717$ \\
\hline V & $3,456.93$ & 18 & 1.190 & 505,512 & $1,243.868$ \\
\hline \multicolumn{6}{|c|}{ Total } \\
\hline
\end{tabular}

Table 4: Lateral forces at each level of a 7-story building

\begin{tabular}{|c|c|c|c|c|c|}
\hline Floor & $w_{i}(\mathrm{kN})$ & $h_{i}$ & $k$ & $w_{i} h_{i}^{k}$ & $F_{i}(\mathrm{kN})$ \\
\hline I & $3,855.97$ & 4 & 1.341 & 413.628 & 103.473 \\
\hline II & $3,816.91$ & 7.5 & 1.341 & 947.961 & 237.142 \\
\hline III & $3,816.91$ & 11 & 1.341 & $1,584.347$ & 396.341 \\
\hline IV & $3,700.14$ & 14.5 & 1.341 & $2,201.145$ & 550.639 \\
\hline V & $3,583.37$ & 18 & 1.341 & $2,817.761$ & 704.892 \\
\hline VI & $3,583.37$ & 21.5 & 1.341 & $3,575.923$ & 894.554 \\
\hline VII & $3,456.93$ & 25 & 1.341 & $4,171.645$ & $1.043,580$ \\
\hline \multicolumn{5}{|c|}{ Total } & $3,930.622$ \\
\hline
\end{tabular}

results of the analysis of static earthquake loads with dynamic earthquake loads. In the analysis of dynamic loads using parameters that have been calculated in the formation of response spectra design is then analyzed in the SAP2000 program using the response spectrum analysis method.

Thus, comparative data obtained from the analysis of static earthquake loads with dynamic earthquake loads can be seen seen in Table 5 .

Based on the results shown in Table 5 it is known that the period of the structure, base shear, and drift in dynamic earthquake loads for the 3-story and 5-story building structures has a smaller value than the static earthquake load calculated based on equivalent static analysis. The smaller result is caused by the calculation of dynamic linear earthquake load using only the value of the formation of the response spectra of the design which is analyzed using response spectrum analysis in the SAP2000 program. Whereas in the calculation of static earthquake loads, there are enlargements of the coefficients for the calculation of the base shear or seismic base force that guarantee the strength and ductility of the building structure to the lateral force of the earthquake load.

But on the contrary the structure of the 7-story building results of the comparison value for the larger base shear and drift is shown by analysis on dynamic earthquake loads. This is due to the static earthquake load calculation for the 7-story building, the value of the seismic response coefficient (Cs) used is maximum, Cs. 
Table 5: Comparison of static earthquake load analysis with dynamic earthquake loads

\begin{tabular}{|c|c|c|c|c|}
\hline $\begin{array}{c}\text { Com- } \\
\text { parison } \\
\text { parameter }\end{array}$ & \begin{tabular}{|c|} 
Building \\
Structure \\
Type \\
\end{tabular} & $\begin{array}{l}\text { Static } \\
\text { seismic } \\
\text { load }\end{array}$ & $\begin{array}{c}\text { Dynamic } \\
\text { seismic } \\
\text { load }\end{array}$ & $\begin{array}{c}\text { Dif- } \\
\text { ferent } \\
(\%) \\
\end{array}$ \\
\hline \multirow{3}{*}{$\begin{array}{l}\text { Vibration } \\
\text { time or } \\
\text { period } \\
\text { of the } \\
\text { structure } \\
\text { (seconds) }\end{array}$} & 3 floors & 0.565 & 0.492 & \\
\hline & 5 floors & 0.880 & 0.518 & \\
\hline & 7 floors & 1.182 & 0.691 & \\
\hline \multirow{3}{*}{$\begin{array}{c}\text { Base } \\
\text { shear } \\
\text { force }(k N)\end{array}$} & 3 floors & 2.227 .996 & 1.788 .951 & 20 \\
\hline & 5 floors & 3728.699 & 3202.629 & 14 \\
\hline & 7 floors & 3930.622 & 4521.467 & 13 \\
\hline \multirow{18}{*}{$\begin{array}{l}\text { Drift in } \mathrm{x} \\
\text {-direction } \\
(\mathrm{mm})\end{array}$} & \multicolumn{4}{|c|}{3 floors } \\
\hline & 1 & 8.194 & 6.513 & 20 \\
\hline & II & 12.440 & 9.672 & 22 \\
\hline & III & 15.089 & 11.532 & 24 \\
\hline & \multicolumn{4}{|c|}{5 floors } \\
\hline & 1 & 10.991 & 9.528 & 13 \\
\hline & II & 17.208 & 14.688 & 15 \\
\hline & III & 22.469 & 18.749 & 17 \\
\hline & IV & 26.769 & 21.782 & 19 \\
\hline & $\mathrm{V}$ & 29.638 & 23.598 & 20 \\
\hline & \multicolumn{4}{|c|}{7 floors } \\
\hline & 1 & 11.406 & 13.239 & 14 \\
\hline & II & 17.966 & 20.596 & 13 \\
\hline & III & 24.104 & 27.033 & 11 \\
\hline & IV & 29.596 & 32.498 & 9 \\
\hline & $\mathrm{V}$ & 34.757 & 37.160 & 6 \\
\hline & $\mathrm{VI}$ & 38.719 & 40.487 & 4 \\
\hline & VII & 41.474 & 42.603 & 3 \\
\hline
\end{tabular}

\section{Comparison of each floors displacement and allowable displacement inspections}

Inter-story drift that occur when the cross section is not allowable to exceed the specified limit. The difference of the inter-story drift must already be multiplied by the deflection magnification factor $(\mathrm{Cd})$ obtained from the choice of structure type. For special moment resisting frame (SMRF) type structures. the Cd value is 5.5.

Allowable drift limit in Table 6 of SNI-1726-2012 for structures with a risk category IV of $0.010 \mathrm{hsx}$. where $h s x$ is the floor height under the floor being reviewed. In this case, the lowest floor height is $4 \mathrm{~m}$. so $\Delta_{\mathrm{a}}=\left(0.010 \times \mathrm{h}_{\mathrm{sx}}\right)=(0.010 \times 4)=0.04 \mathrm{~m}=40 \mathrm{~mm}$. For floors above it, $\Delta_{\mathrm{a}}=(0.010 \times 3.5)=0.035 \mathrm{~m}=35 \mathrm{~mm}$.

The inter-story drift assessment is shown in the following tables.

Based on the comparison results between static earthquake loads and dynamic earthquake loads and drifts
Table 6: Examination of drift due to earthquake force design for $\mathrm{x}$-direction on a 3-story building

\begin{tabular}{|c|c|c|c|c|c|}
\hline Floor & $\begin{array}{c}\text { Height } \\
(\mathrm{m})\end{array}$ & $\begin{array}{c}\text { drift } \delta_{\mathrm{e}} \\
(\mathrm{mm})\end{array}$ & $\begin{array}{c}\text { Inter } \\
\text { floor } \\
\text { drift } \\
\Delta(\mathrm{mm})\end{array}$ & $\begin{array}{c}\Delta_{\mathrm{a}} \\
(\mathrm{mm})\end{array}$ & Description \\
\hline I & 4 & 8.194 & 30.04 & 40 & fulfilled \\
\hline II & 7.5 & 12.440 & 15.57 & 35 & fulfilled \\
\hline III & 11 & 15.089 & 9.71 & 35 & fulfilled \\
\hline
\end{tabular}

Table 7: Examination of drift due to earthquake force design for $\mathrm{x}$-direction on a 5-story building

\begin{tabular}{|c|c|c|c|c|c|}
\hline Floor & $\begin{array}{c}\text { Height } \\
(\mathrm{m})\end{array}$ & $\begin{array}{c}\text { drift } \delta_{\mathrm{e}} \\
(\mathrm{mm})\end{array}$ & $\begin{array}{c}\text { Inter } \\
\text { floor } \\
\text { drift } \\
\Delta(\mathrm{mm})\end{array}$ & $\begin{array}{c}\Delta_{\mathrm{a}} \\
(\mathrm{mm})\end{array}$ & Description \\
\hline I & 4 & 10.991 & 40.30 & 40 & fulfilled \\
\hline II & 7.5 & 17.208 & 22.80 & 35 & fulfilled \\
\hline III & 11 & 22.469 & 19.29 & 35 & fulfilled \\
\hline IV & 14.5 & 26.769 & 15.77 & 35 & fulfilled \\
\hline V & 18 & 29.638 & 10.52 & 35 & fulfilled \\
\hline
\end{tabular}

Table 8: Examination of drift due to earthquake force design for $\mathrm{x}$-direction on a 7-story building

\begin{tabular}{|c|c|c|c|c|c|}
\hline Floor & $\begin{array}{c}\text { Height } \\
(\mathrm{m})\end{array}$ & $\begin{array}{c}\text { drift } \delta_{\mathrm{e}} \\
(\mathrm{mm})\end{array}$ & $\begin{array}{c}\text { Inter } \\
\text { floor } \\
\text { drift } \\
\Delta(\mathrm{mm})\end{array}$ & $\begin{array}{c}\Delta_{\mathrm{a}} \\
(\mathrm{mm})\end{array}$ & Description \\
\hline I & 4 & 11.406 & 41.82 & 40 & fulfilled \\
\hline II & 7.5 & 17.966 & 24.05 & 35 & fulfilled \\
\hline III & 11 & 24.104 & 22.51 & 35 & fulfilled \\
\hline IV & 14.5 & 29.596 & 20.14 & 35 & fulfilled \\
\hline $\mathrm{V}$ & 18 & 34.757 & 18.92 & 35 & fulfilled \\
\hline $\mathrm{VI}$ & 21.5 & 38.719 & 14.53 & 35 & fulfilled \\
\hline $\mathrm{VII}$ & 25 & 41.474 & 10.10 & 35 & fulfilled \\
\hline
\end{tabular}

that occur, it can be seen most have met the allowable drift limit for each type of building structure. With a 30 $\mathrm{MPa}$ concrete compressive strength used to obtain a more efficient cross-sectional dimension of the structure, has met the requirements for earthquake resistance planning for building structures in accordance with SNI1726-2012 [6]. The material quality and geometry data can be shown in Table 9. Thus the structure of the building can withstand tsunami loads.

\section{Tsunami load calculation}

Using calculation steps that refer to FEMA P646 of 2012, the results of calculations for tsunami forces with maximum elevation parameters of different inundation at each type of building height are shown in Table 10. 
Table 9: Data of material quality and geometry of building structures

\begin{tabular}{|c|c|c|c|}
\hline & \multicolumn{3}{|c|}{ Building Structure } \\
\hline & 3 Floors & 5 Floors & 7 Floors \\
\hline $\begin{array}{c}\text { Concrete } \\
\text { Quality (f'c) }\end{array}$ & 30MPa & 30MPa & $30 \mathrm{MPa}$ \\
\hline $\begin{array}{l}\text { Modulus of } \\
\text { elasticity (Ec) }\end{array}$ & $25743 \mathrm{MPa}$ & $25743 \mathrm{MPa}$ & $25743 \mathrm{MPa}$ \\
\hline \multirow{2}{*}{$\begin{array}{l}\text { Column of } 1 \\
\text { reinforcement }\end{array}$} & $\begin{array}{c}500 / 500 \\
\mathrm{~mm}\end{array}$ & $\begin{array}{c}600 / 600 \\
\mathrm{~mm}\end{array}$ & $\begin{array}{c}600 / 600 \\
\mathrm{~mm}\end{array}$ \\
\hline & $\begin{array}{l}16 \mathrm{D} 19 . \\
\rho s=2 \%\end{array}$ & $\begin{array}{c}\begin{array}{c}24 \mathrm{D} 19 . \\
\rho s=2.1 \%\end{array} \\
\end{array}$ & $\begin{array}{c}28 D 19 . \\
\rho s=2.4 \%\end{array}$ \\
\hline \multirow{2}{*}{$\begin{array}{l}\text { Column of } 2 \\
\text { reinforcements }\end{array}$} & $\begin{array}{c}450 / 450 \\
\mathrm{~mm}\end{array}$ & $\begin{array}{c}550 / 550 \\
\mathrm{~mm}\end{array}$ & $\begin{array}{c}550 / 550 \\
\mathrm{~mm}\end{array}$ \\
\hline & $\begin{array}{c}\text { 12D19. } \\
\rho s=1.86 \%\end{array}$ & $\begin{array}{c}20 \mathrm{D} 19 . \\
\rho s=2.1 \%\end{array}$ & $\begin{array}{c}20 \mathrm{D} 19 . \\
\rho s=2.1 \%\end{array}$ \\
\hline Beam 1 & $\begin{array}{c}300 / 600 \\
\mathrm{~mm}\end{array}$ & $\begin{array}{c}350 / 650 \\
\mathrm{~mm}\end{array}$ & $\begin{array}{c}400 / 650 \\
\mathrm{~mm}\end{array}$ \\
\hline Beam 2 & $\begin{array}{c}350 / 700 \\
\mathrm{~mm}\end{array}$ & $\begin{array}{c}400 / 800 \\
\mathrm{~mm}\end{array}$ & $\begin{array}{c}450 / 800 \\
\mathrm{~mm}\end{array}$ \\
\hline Beam 3 & $\begin{array}{c}300 / 500 \\
\mathrm{~mm}\end{array}$ & $\begin{array}{c}300 / 500 \\
\mathrm{~mm}\end{array}$ & $\begin{array}{c}300 / 500 \\
\mathrm{~mm}\end{array}$ \\
\hline B1 roof & $\begin{array}{c}300 / 500 \\
\mathrm{~mm}\end{array}$ & $\begin{array}{c}300 / 500 \\
\mathrm{~mm}\end{array}$ & $\begin{array}{c}300 / 500 \\
\mathrm{~mm}\end{array}$ \\
\hline B2 roof & $\begin{array}{c}300 / 600 \\
\mathrm{~mm}\end{array}$ & $\begin{array}{c}300 / 600 \\
\mathrm{~mm}\end{array}$ & $\begin{array}{c}300 / 600 \\
\mathrm{~mm}\end{array}$ \\
\hline B4/ joist & $\begin{array}{c}250 / 400 \\
\mathrm{~mm}\end{array}$ & $\begin{array}{c}250 / 400 \\
\mathrm{~mm}\end{array}$ & $\begin{array}{c}250 / 400 \\
\mathrm{~mm}\end{array}$ \\
\hline Roof beam & $\begin{array}{c}200 / 400 \\
\mathrm{~mm}\end{array}$ & $\begin{array}{c}200 / 400 \\
\mathrm{~mm}\end{array}$ & $\begin{array}{c}200 / 400 \\
\mathrm{~mm}\end{array}$ \\
\hline $\begin{array}{l}\text { Plate } \\
\text { thickness }\end{array}$ & $120 \mathrm{~mm}$ & $120 \mathrm{~mm}$ & $120 \mathrm{~mm}$ \\
\hline
\end{tabular}

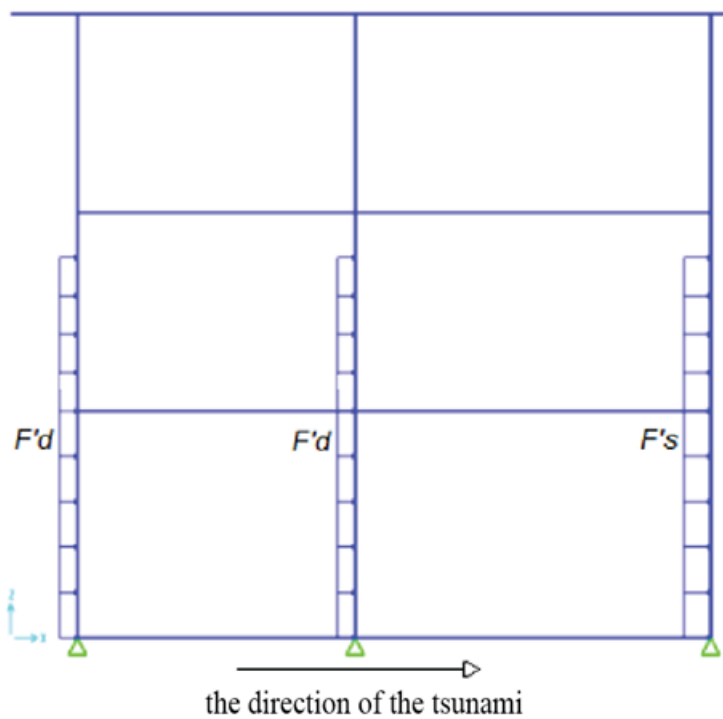

Figure 2: Application of combined tsunami force 1 (T1)
Table 10: Tsunami forces with different maximum elevation variables

\begin{tabular}{|c|c|c|c|c|c|}
\hline \multirow{2}{*}{ Variable } & \multirow{2}{*}{$\begin{array}{l}\text { For- } \\
\text { mula }\end{array}$} & \multicolumn{3}{|c|}{$\begin{array}{l}\text { Maximum inundation } \\
\text { elevation }\left(R^{*}\right)\end{array}$} & \multirow{2}{*}{ Unit } \\
\hline & & $(9 m)$ & $(12.5 \mathrm{~m})$ & $(16 \mathrm{~m})$ & \\
\hline $\begin{array}{c}\text { Rising } \\
\text { tsunami }\end{array}$ & $R$ & 11.7 & 16.25 & 20.8 & $m$ \\
\hline \multirow{3}{*}{$\begin{array}{l}\text { Hydrody } \\
\text { namic } \\
\text { force }\end{array}$} & $F_{d \text { kolom }}$ & 323.5 & 1058.1 & 2056.6 & $k N$ \\
\hline & $F_{d \text { kolom }}^{\prime}$ & 48.3 & 94.1 & 130.2 & $\mathrm{kNm}$ \\
\hline & $F_{d \text { dinding }}^{\prime}$ & 96.6 & 156.8 & 216.9 & $\mathrm{kN} \mathrm{m}^{2}$ \\
\hline \multirow{3}{*}{$\begin{array}{l}\text { Impulsive } \\
\text { force }\end{array}$} & $F_{\text {skolom }}$ & 485.2 & 1587.1 & 3084.9 & $k N$ \\
\hline & $F_{\text {skolom }}^{\prime}$ & 72.4 & 141.1 & 195.2 & $k N m$ \\
\hline & $F_{s \text { dinding }}^{\prime}$ & 144.8 & 235.1 & 325.4 & $\mathrm{kN} \mathrm{m}^{2}$ \\
\hline \multirow{2}{*}{$\begin{array}{l}\text { Impact } \\
\text { force }\end{array}$} & $F_{i}$ & 810.8 & 1552.8 & 1945.9 & $k N$ \\
\hline & $F_{i}+F_{d}$ & 1134.3 & 2610.8 & 4002.5 & $k N$ \\
\hline $\begin{array}{c}\text { Debris } \\
\text { damming } \\
\text { loads (3 } \\
\text { columns) }\end{array}$ & $F_{d m}^{\prime}$ & 386.3 & 627 & 867.7 & $k N / m$ \\
\hline $\begin{array}{l}\text { Hydrody- } \\
\text { namic } \\
\text { Lift Force }\end{array}$ & $F_{u}$ & 0.588 & 1.849 & 2.746 & $k N m^{2}$ \\
\hline
\end{tabular}

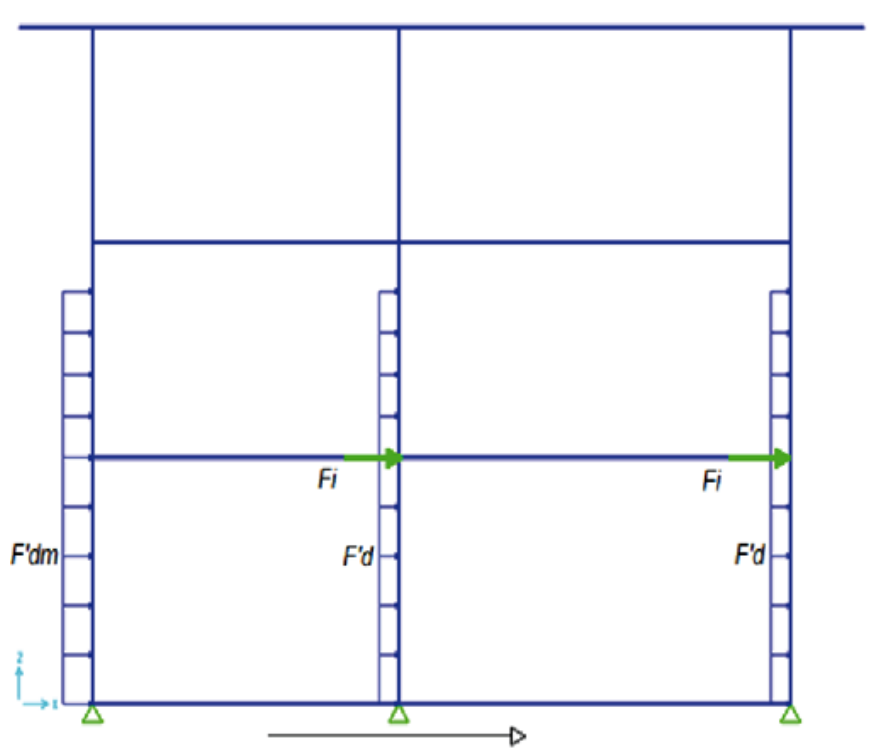

the direction of the tsunami

Figure 3: Application of combined tsunami force 2 (T2)

\section{Apply forces to the structure}

The application of tsunami forces for each type of building height is adjusted to the combination tsunami load 1 (T1) and combination tsunami 2 (T2) as shown in the following Figure 2 and Figure 3. 


\section{Comparison of internal Forces due to Earthquake Load Combination Tsunami 1 (T1) and Combination Tsunami 2 (T2)}

Comparison of internal forces includes moment (M), shear force (D), and axial force (N) for columns while for beams only (M) and (D). Due to the assumption of the arrival of tsunami waves from the x-axis direction, therefore to compare the results of internal forces for earthquake loads, T1, and T2 uses load combinations of $1.2 \mathrm{D}+1.0 \mathrm{~L}+1.0 \mathrm{Ex}+0.3 \mathrm{Ey}$ for earthquake loads and $1.2 \mathrm{D}+1 \mathrm{Ts}+1 \mathrm{Lref}+0.25 \mathrm{~L}$ for tsunami load. An evaluation of the results of the analysis is carried out on the values of the internal forces for the first floor column viewed from the exterior column namely column 1 on Grid and interior column. i.e. column on Grid 4 and for the beam being reviewed namely Grid 1 beam and Grid 4 beam.

For a clearer picture of the position of the reviewed column and beam elements can be seen in Figure 4 .

The purpose of the evaluation on the comparison of maximum internal forces on column and beam elements in terms of the 3-story. 5-story and 7-story building structure is to find out how the structure behaves at each column and beam position in terms of earthquake loads T1 and Q2. The maximum internal forces of the column on the first floor shown in Table 11 show that the maximum moment in the column lying in column Grid B-1 for earthquake loads and T1. This is because the column in that position carries the greatest axial load coupled with the presence of lateral force from an earthquake and tsunami loads. Whereas at T2 the maximum moment lies in the Grid B-4 column because of the impact load acting on the column in that position.

The maximum shear force for earthquake loads and T1 lies in the Grid C-1 column because in that column it con-

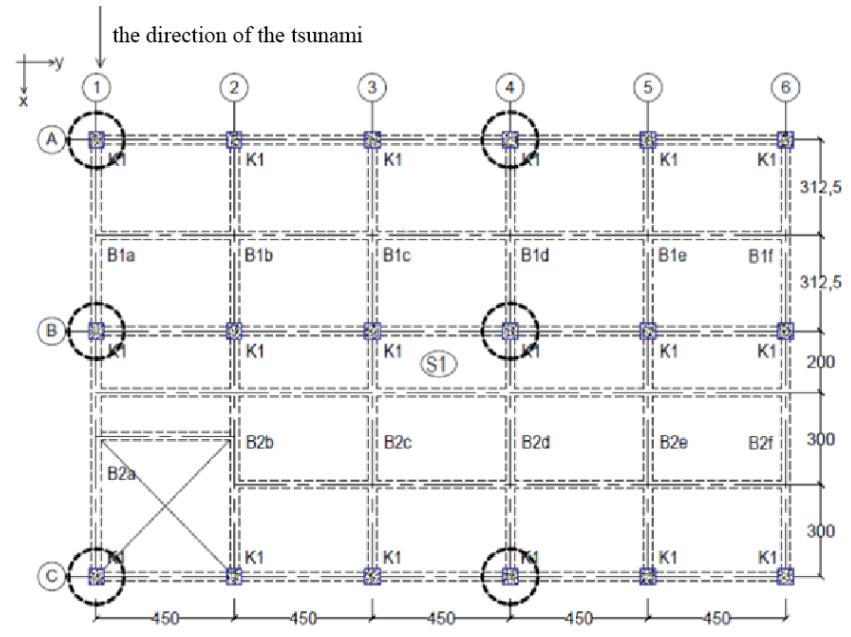

Figure 4: The position of the reviewed columns and beams

tinues the lateral load from the Grid A-1 column and the Grid B-2 column. so that the column at the very back of the structure towards the direction of the tsunami wave is carrying greatest shear force. At T2 the maximum shear force lies in the Grid A-4 column because the collision load works directly on the column in that position.

The maximum axial force for earthquake loads is in the Grid B-4 column due to greater axial load from the dead load (DL) and live load (LL) when compared to the columns located on Grid A and Grid C, whereas the maximum axial force for T1 and T2 lies in the Grid C. This column is caused by the large lateral force received by the front column which was hit by a tsunami inundation so as if there was a leverage effect on the structure; thus giving a lifting effect to the Grid A column so that the column in Grid $C$ receives a compressive effect which adds to the amount of axial force received by the column at that position.

Table 11: The styles in the maximum column on the first floor

\begin{tabular}{|c|c|c|c|c|c|c|}
\hline \multirow{2}{*}{ Building Type } & \multicolumn{7}{|c|}{ A 3-story Building } \\
\cline { 2 - 7 } & earthquake & Column Position & T1 & Column Position & T2 & Column Position \\
\hline M (kNm) & -257.3 & B-1 & -653.9 & B-1 & -1492.6 & B-4 \\
\hline D (kN) & 239.9 & C-1 & 493.1 & B-1 & 1010.1 & A-4 \\
\hline N (kN) & -1013.2 & B-4 & -891.5 & C-4 & -932.9 & C-4 \\
\hline \multirow{2}{*}{ Building Type } & \multicolumn{7}{|c|}{ A 5-story Building } \\
\cline { 2 - 8 } & earthquake & Column Position & T1 & Column Position & T2 & Column Position \\
\hline M (kNm) & -529.5 & B-1 & -2249.6 & B-1 & -5353.9 & B-4 \\
\hline D (kN) & 371.9 & C-1 & 1182.9 & C-1 & 1784.2 & A-4 \\
\hline N (kN) & -1681.1 & B-4 & -2143.6 & C-1 & -3833.9 & C-4 \\
\hline \multirow{2}{*}{ Building Type } & \multicolumn{7}{|c|}{ A 7-story Building } & T2 & Column Position \\
\cline { 2 - 8 } & earthquake & Column Position & T1 & Column Position & T2 \\
\hline M (kNm) & -566.1 & B-1 & -4863.7 & B-1 & -8644.8 & B-4 \\
\hline D (kN) & 390.1 & C-1 & 1863.5 & C-1 & 3429.7 & A-4 \\
\hline N (kN) & -2318.2 & B-4 & -4776.1 & C-1 & -8282.8 & C-4 \\
\hline
\end{tabular}




\section{Drift and Drift Ratio}

Results of story drift from the analysis due to earthquake loading, T1, and T2 in the building structure can then be calculated as drift ratio. The drift ratio is the ratio of drift between levels $(\Delta)$ and level height $(\mathrm{h})$. Maximum drift in a combination of earthquake loads used drifts that have been multiplied by the deflection magnification factor (Cd) which has been calculated so as not to exceed the allowable inter-story drift limit in accordance with Table 16 of SNI-1726-2012 while the results of drift for tsunami loads are obtained directly from the analysis results of structure in the SAP2000 program.

Drift ratio comparison graphs between earthquake loads, $\mathrm{T} 1$, and T2 for building types with a height of 3 floors, 5 floors, and 7 floors are shown respectively in Figure 3, Figure 4 and Figure 5, while the drift ratio is presented in Table 12, Table 13, and Table 14.

Table 12: Comparison of drift and drift ratio in a 3-story building

\begin{tabular}{|c|c|c|c|c|c|c|c|}
\hline \multirow{2}{*}{ Floor } & \multirow{2}{*}{$\begin{array}{c}\text { Height } \\
(\mathrm{m})\end{array}$} & \multicolumn{3}{|c|}{ Drift $\delta(\mathrm{mm})$} & \multicolumn{3}{c|}{ Drift Ratio (\%) } \\
\cline { 3 - 8 } & $\mathrm{G}$ & $\mathrm{T} 1$ & $\mathrm{~T} 2$ & $\mathrm{G}$ & $\mathrm{T} 1$ & $\mathrm{~T} 2$ \\
\hline I & 4 & 30.04 & 20.70 & 40.21 & 0.75 & 0.52 & 1.01 \\
\hline II & 7.5 & 45.61 & 24.79 & 50.84 & 0.44 & 0.12 & 0.30 \\
\hline III & 11 & 55.33 & 25.16 & 51.72 & 0.28 & 0.01 & 0.03 \\
\hline
\end{tabular}

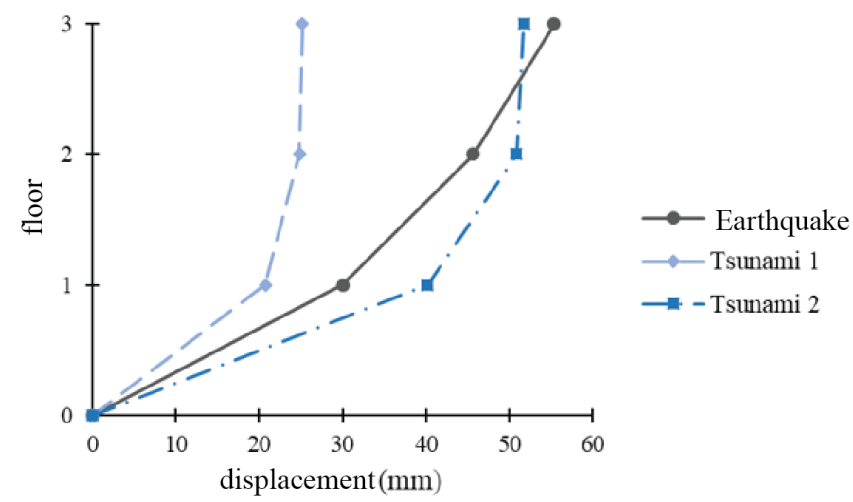

Figure 5: Drift graph of a 3-storey building

Table 13. Comparison of drift and drift ratio in a 5-story building

\begin{tabular}{|c|c|c|c|c|c|c|c|}
\hline \multirow{2}{*}{ Floor } & \multirow{2}{*}{$\begin{array}{c}\text { Height } \\
(\mathrm{m})\end{array}$} & \multicolumn{3}{|c|}{ Drift $\delta(\mathrm{mm})$} & \multicolumn{3}{c|}{ Drift Ratio $(\%)$} \\
\cline { 3 - 8 } & & $\mathrm{G}$ & $\mathrm{T} 1$ & $\mathrm{~T} 2$ & $\mathrm{G}$ & $\mathrm{T} 1$ & $\mathrm{~T} 2$ \\
\hline I & 4 & 40.30 & 57.63 & 85.26 & 1.01 & 1.44 & 2.13 \\
\hline II & 7.5 & 63.10 & 79.71 & 136.69 & 0.65 & 0.63 & 1.47 \\
\hline III & 11 & 82.39 & 88.61 & 169.03 & 0.55 & 0.25 & 0.92 \\
\hline IV & 14.5 & 98.15 & 90.30 & 185.29 & 0.45 & 0.05 & 0.46 \\
\hline V & 18 & 108.67 & 90.91 & 189.67 & 0.30 & 0.02 & 0.13 \\
\hline
\end{tabular}

In the 3-story building structure, drift values due to earthquake loads, T1, and T2 still meet the allowable inter-story drifts. The maximum drift ratio value on the first floor of a 3-story building structure due to earthquake loads,

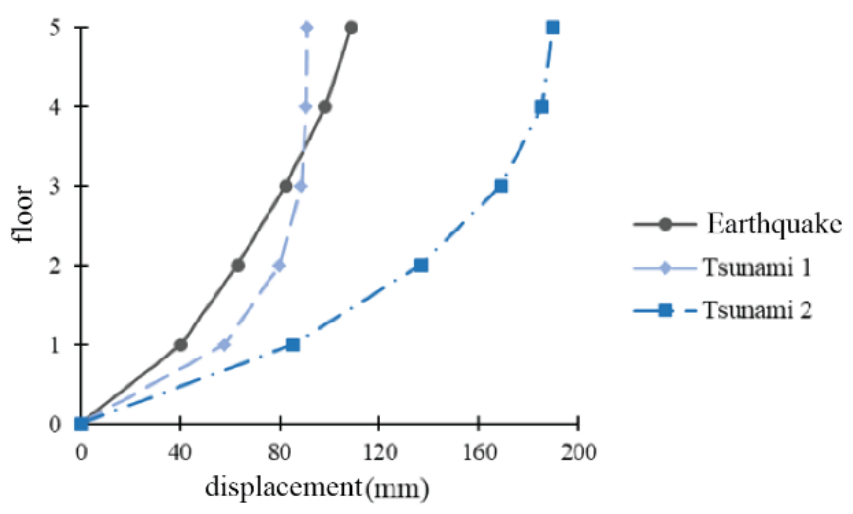

Figure 6: Drift graph of a 5-storey building

Table 14: Comparison of drift and drift ratio in a 7-story building

\begin{tabular}{|c|c|c|c|c|c|c|c|}
\hline \multirow{2}{*}{ Floor } & Height & \multicolumn{3}{|c|}{ Drift $\delta(\mathrm{mm})$} & \multicolumn{3}{c|}{ Drift Ratio $(\%)$} \\
\cline { 3 - 8 } & $(\mathrm{m})$ & $\mathrm{G}$ & $\mathrm{T} 1$ & $\mathrm{~T} 2$ & $\mathrm{G}$ & $\mathrm{T} 1$ & $\mathrm{~T} 2$ \\
\hline $\mathrm{I}$ & 4 & 41.82 & 115.26 & 186.76 & 1.05 & 2.88 & 4.67 \\
\hline II & 7.5 & 65.88 & 166.69 & 309.00 & 0.69 & 1.47 & 3.49 \\
\hline III & 11 & 88.38 & 199.03 & 408.05 & 0.64 & 0.92 & 2.83 \\
\hline $\mathrm{IV}$ & 14.5 & 108.52 & 215.29 & 461.03 & 0.58 & 0.46 & 1.51 \\
\hline $\mathrm{V}$ & 18 & 127.44 & 219.67 & 474.40 & 0.54 & 0.13 & 0.38 \\
\hline $\mathrm{VI}$ & 21.5 & 141.97 & 221.40 & 479.01 & 0.42 & 0.05 & 0.13 \\
\hline $\mathrm{VII}$ & 25 & 152.07 & 222.98 & 483.04 & 0.29 & 0.04 & 0.12 \\
\hline
\end{tabular}

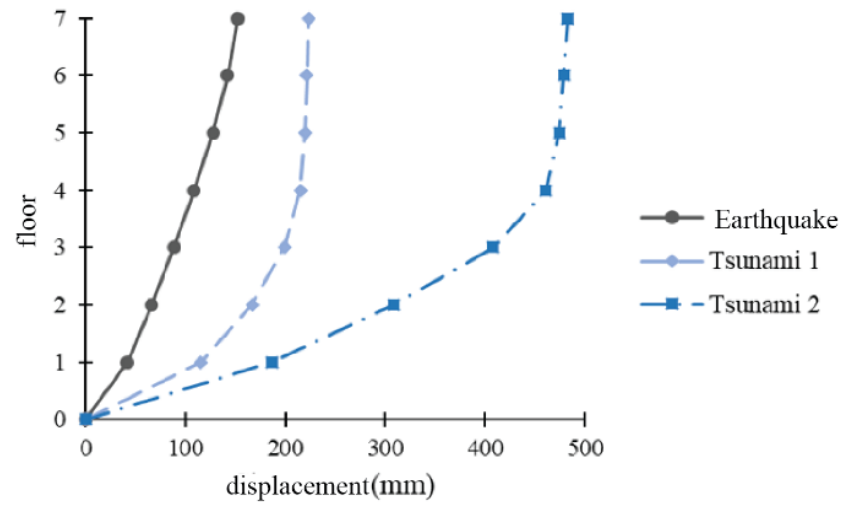

Figure 7. Drift graph of a 7-storey building

$\mathrm{T} 1$, and $\mathrm{T} 2$ are $0.75 \%, 0.52 \%$, and $1.01 \%$, respectively, which are all smaller than the building drift ratio limit with a IV-risk category that is equal to $1 \%$.

In the structure of buildings 5 and 7 floors, the value of the drift ratio on the first floor due to earthquake load has fulfilled the requirements $(<1 \%)$. but conversely due to the load T1 and T2 at the same floor level. the drift ratio of 5 -storey buildings is respectively $1.44 \%$ and $2.13 \%$. while in the 7 -story building respectively $2.88 \%$ and $4.67 \%$.

\section{CONCLUSION}

From the results of research and discussion on the effect of earthquake and tsunami loads on the behavior of reinforced concrete structures, evaluation of the analysis 
results is carried out on the values of internal forces, drift and drift ratio so that the following conclusions can be drawn:

1. For a comparison of the internal forces of column and beam elements due to earthquake and tsunami load effects. a review is carried out on the elements in Grid 1 and Grid 4 selected to represent the building's exterior and interior structural elements.

2. In the 3-story building structure, drift values due to earthquake loads, T1, and T2 still meet the allowable inter-story drifts. The maximum drift ratio value on the first floor of the 3-story building structure due to earthquake loads, T1, and T2 are $0.75 \% .0 .52 \%$ and $1.01 \%$, which are all smaller than the limits allowed for buildings categorized as risk IV, namely by $1 \%$. The results of story drift and drift ratio on the 3-story building structure meet the allowable inter-story drifts and drift ratio limits. It can be seen that the structure is resistant to earthquake loads and also planned tsunami loads.

3. In the 5 and 7-story building structure, the drift ratio value on the first floor only due to the earthquake load fulfilled the requirements $(<1 \%)$, conversely, the drift ratio of a 5-story building due to the load T1 and T2 is respectively $1.44 \%$ and $2.13 \%$, while the 7 -story building is respectively $2.88 \%$ and $4.67 \%$. From the results it can be concluded that the 5 and 7-story building structures can support the earthquake load but not able to withstand the lateral forces due to the planned tsunami loads (T1 and T2)

\section{RECOMMENDATION}

The calculation of tsunami loading on buildings still refers to the American standard, namely FEMA P646-2012. It is recommended that the Indonesian government should provide tsunami loading guidance related to Indonesian conditions.

\section{REFERENCES}

1. Rukin, (2020), Economic Development of Coastal Village Communities as Increase Welfare Efforts, Jurnal Sosial Humaniora p-ISSN 2087-4928 e-ISSN 2550-0236 Volume 11 Nomor 1, April 2020.

2. Saatcioglu M.. Ghobarah A. and Nistor I..(2005) "Effects of the December 26. 2004 Sumatra Earthquake and Tsunami on Physical Infrastructure". ISET Journal of Earthquake Technology. Paper No. 457. Vol. 42. No. 4. December. pp. 79-94.

3. FEMA P646. 2012. Guidelines for Design of Structures for Vertical Evacuation from Tsunamis. Applied Technology Council. FEMA. Washington. DC.
4. Hamzah, L., Puspito, N. T., \& Imamura, F. (2000). Tsunami catalog and zones in Indonesia. Journal of Natural Disaster Science, 22(1), 25-43.

5. Lovholt, F., Kuhn, D., Bungum, H., Harbitz, C. B., \& Glimsdal, S. (2012). Historical tsunamis and present tsunami hazard in eastern Indonesia and the southern Philippines. Journal of Geophysical Research: Solid Earth, 117(B9).

6. SNI 1726-2012: Tata Cara Perencanaan Ketahanan Gempa untuk Struktur Bangunan Gedung dan Non Gedung (Earthquake Resistant Planning Procedures for Building and Non-Building Structures). National Standardization Agency. Jakarta. 2012.

7. Post, J., Wegscheider, S., Muck, M., Zosseder, K., Kiefl, R., Steinmetz, T., \& Strunz, G. (2009). Assessment of human immediate response capability related to tsunami

8. Wegscheider, S., Post, J., Zosseder, K., Mück, M., Strunz, G., Riedlinger, T., \& Anwar, H. Z. (2011). Generating tsunami risk knowledge at community level as a base for planning and implementation of risk reduction strategies. Natural Hazards and Earth System Sciences, 11(2), 249-258.

9. Stolle, J., Krautwald, C., Robertson, I., Achiari, H., Mikami, T., Nakamura, R., \& Nistor, I. (2020). Engineering lessons from the 28 September 2018 Indonesian tsunami: debris loading. Canadian Journal of Civil Engineering, 47(1), 1-12.

10. Joshua M., Alison R., Antonios P., Ioan N., Sean W. and Tiziana R., (2018) Tsunami design procedures for engineered buildings: a critical review, Civil Engineering 171(4):1-60, ICE publishing., DOI: 10.1680/ jcien.17.00043

11. Panitan L. and Ruangrassamee, A. 2008. Building damage in Thailand in the 2004 Indian Ocean tsuna$\mathrm{mi}$ and clues for tsunami-resistant design. The IES Journal Part A: Civil \& Structural Engineering. Volume 1, Issue 1.

12. Siswanto A.B., Afif S.M., (2018), Basic Criteria Design Of Earthquake Resistant Building Structures, International Journal of Civil Engineering and Technology (IJCIET) Volume 9, Issue 4, April 2018, pp. 1426-1436, Article ID: IJCIET_09_04_158 , ISSN Print: 0976-6308 and ISSN Online: $097 \overline{6}-6316$

13. Gary Y.K.C., Dist., Lyle C., lan R., Yong W., (2018), Tsunami Resilient Building Design Consideration For Coastal Communities Of Washington, Oregon, And California, ASCE., Journal Of Structural Engineering, Volume 144, Issue 8- August. 
14. Imran, I., Yuniarsyah, E., Edrea, F., Piranti, S.N., Faiza, F., Binarandi, G. (2013). Pedoman Teknik Perancangan Struktur Bangunan Tempat Evakuasi Sementara (TES) Tsunami Badan Nasional Penanggulangan Bencana (BNPB). Jakarta

15. Hall, S., Emmett, C., Cope, A., Harris, R., Setiadi, G. D., Meservy, W., \& Berrett, B. (2019). Tsunami knowledge, information sources, and evacuation intentions among tourists in Bali, Indonesia. Journal of Coastal Conservation, 23(3), 505-519.
16. SNI 1727-2013: Beban Minimum untuk Perancangan Bangunan Gedung dan Struktur Lain (Minimum Load for Building Design and Other Structures). National Standardization Agency. Jakarta. 2013. 